\title{
Deep thermomodernization of three residential buildings in Kryvyi Rih, Ukraine
}

\author{
Kamil Różycki ${ }^{1, *}$ \\ ${ }^{1}$ Warsaw University of Technology, Division of Refrigeration and Energy in Buildings, Nowowiejska \\ 21/25, 00-665 Warsaw, Poland
}

\begin{abstract}
This article presents the energy balance conditions of three multi-family residential buildings located in Kryvyi Rih, Ukraine. These buildings were built more than 40 years ago and are not insulated. A significant amount of energy is lost by the external partitions. The building's heating is powered by municipal natural gas. A proposal for several thermomodernization variants for selected facilities are presented in the article. These variants of deep thermomodernization include an upgrade of the heating installation, insulation of external walls and roof, and the replacement of windows and doors in common areas. In view of the recent increases in the gas prices, the internal building's temperature is maintained below the thermal comfort. The presented variants include the proposal to leave the internal temperature at the present level, as well as to increase it to $20{ }^{\circ} \mathrm{C}$. Heat transfer coefficients were calculated based on of the PN-EN 6946 standard and the heat demand for the buildings was estimated in the standard reference year in accordance with the PN-EN ISO 13790 standard. Results are compared with real values. The buildings' models were prepared in the Audytor OZC 6.7. Pro software. The impact of appropriately sized photovoltaic system for each of the objects was also analyzed and the solar irradiation data has been taken from the RETScreen 4 software.
\end{abstract}

\section{Introduction}

This work analyzes the energy balance of the three selected, characteristic residential buildings belonging to housing communities in Ukraine, located in Kryvyi Rih. This analysis and its results may translate into larger scale projects in the future, even considering the whole city, in which most of the buildings are similar to those described in this article. Like in most countries around the world, the problems with increasing energy demand and environmental pollution are real in Ukraine. One of the main ways to reduce energy consumption and greenhouse gas emissions is by improving energy efficiency. From among all sectors, one of the most energy-intensive in this country, and at the same time almost unmodernized, is the building sector. The majority of buildings in Ukraine have not undergone any energy upgrades. They are not insulated, heating systems are outdated, while natural gas prices are still growing. In Ukraine, at on the $1^{\text {st }}$ of July 2016 ,

\footnotetext{
${ }^{*}$ Corresponding author: krozycki@itc.pw.edu.pl
} 
the natural gas price had doubled. This resulted in the need to reduce spending on heat. The reduction of energy consumption has been achieved by lowering the temperature maintained indoors, even below thermal comfort. For many people living in residential apartment buildings, the costs of utility bills are a significant portion of the whole financial balance of the flat. Even though they get special subsidies, it is not enough to encourage people to maintain thermal comfort in their homes.

In Ukraine, as in other countries, the most sensible solution seems to be a deep thermomodernization of the whole group of buildings. This investment will result in reducing the energy demand for those buildings, while simultaneously allowing reduction of unit costs for each building. The three selected multi-family residential buildings in this analysis were deliberately chosen, as each of them represents a specific type of building common in Kryvyi Rih. Performing an energy balance analysis for these facilities may be the basis for determining the costs of modernization of all local residential buildings and for carrying out a thermomodernization of the whole city.

There is a support system in Ukraine promoting the use of renewable energy sources. Therefore, it was decided to also consider installation of a photovoltaic system on each building. Some electricity can cover shared energy consumption in buildings and the remaining energy can be sold to the grid. All prices and costs given in this article are gross value.

The DREEAM project, financed by Horizon 2020 (http://dreeam.eu/), whose Polish partner is the National Energy Conservation Agency, encourages such deep, multi-building thermomodernization combined with the use of renewable energy. The DREEAM project aims to show that thermomodernization of buildings on a larger scale, combined with the use of renewable energy sources is more profitable than the traditional method of modernization of individual facilities. The project indicates activities that may reduce energy demand by up to $75 \%$. The project consists of two parts. One is devoted to practical actions that will result in a deep thermomodernization in three pilot European locations: Padiham in Great Britain, Treviso in Italy and Berlin in Germany. The second part of the project assumes the preparation of energy audits in other locations that will show the potential of saving energy in different European countries, including Ukraine. The results are intended to prove that regardless of the climate, cultural differences or institutional activities the ideas included in this project can bring enormous benefits, and therefore it is encouraged to replicate this approach across Europe. The results of the project can be the basis for creation of nationwide thermomodernization support programs, fitting to the specific local conditions.

\section{Basic information on the examined buildings}

In the city of Kryvyi Rih in Ukraine there are thousands of buildings and most of them are not insulated. Three buildings were selected for this analysis. Each of them belongs to one of three groups. Each group consists of a different set of objects specific for this region. The first group includes 3-4-storey buildings made of bricks (further referred as building 1). The second group are 4-5-storey buildings made of reinforced concrete slabs (further referred as building 2), and the third one is over 6-story buildings (further referred as building 3), also made of reinforced concrete slabs. The examined buildings do not have a central hot water distribution system, it was not considered in this analysis. Table 1 contains the most important information about selected buildings. 
Table 1. General information about the examined buildings.

\begin{tabular}{|l|c|c|c|c|}
\hline Number of building group & Unit & Building 1 & Building 2 & Building 3 \\
\hline Year of construction & {$[$ year] } & 1954 & 1968 & 1970 \\
\hline Number of floors & {$[\mathrm{no}]$} & 5 & 5 & 9 \\
\hline Number of people living in the building & {$[\mathrm{no}]$.} & 33 & 165 & 431 \\
\hline Heated area & {$\left[\mathrm{m}^{2}\right]$} & $1,070.7$ & $4,222.1$ & $10,592.0$ \\
\hline
\end{tabular}

\section{Methodology and examination results}

\subsection{Thermomodernization of selected buildings}

The considered buildings are characterized by lack of external partitions thermal insulation and lack of heating installation pipes insulation. It should be considered which modernization variants to carry out, so that the costs incurred can be repaid by the difference in the heat bills. Calculation of the heat demand for buildings in the standard reference year were made using monthly balance method based on PN-EN ISO 13790 [2]. Heat transfer coefficients were calculated on the basis of the PN EN 6946 standard [3]. Computer models of the buildings were made in the Audytor OZC 6.7 Pro software. In addition, the designated results were compared with results from the program which confirmed the correctness of the calculations made. Figures 1,2 and 3 contain visualizations of buildings modeled in this program.

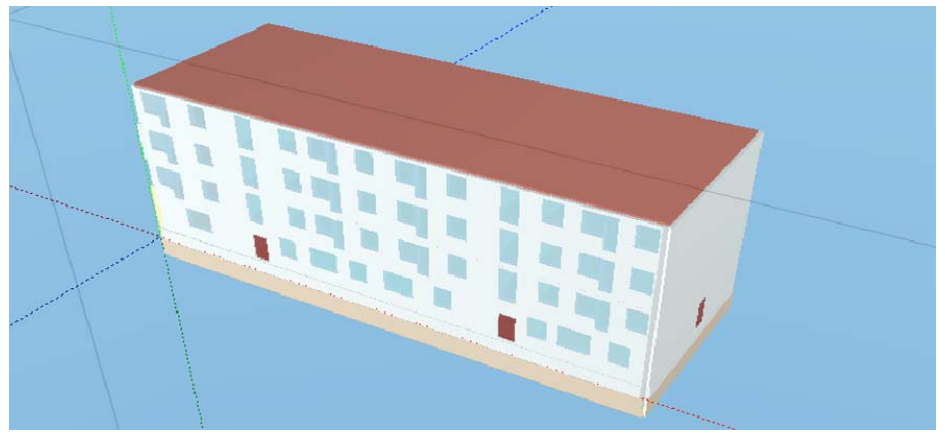

Fig. 1. Building 1 - visualization made in the Audytor OZC 6.6 Pro program.

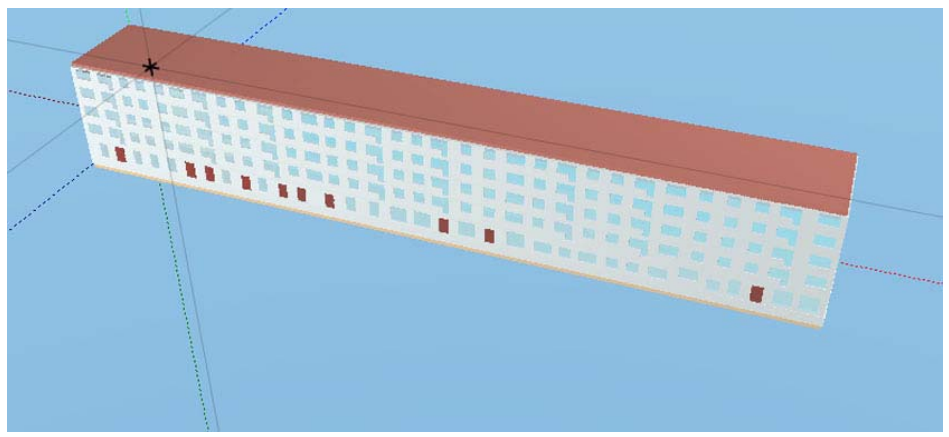

Fig. 2. Building 2 - visualization made in the Audytor OZC 6.6 Pro program. 


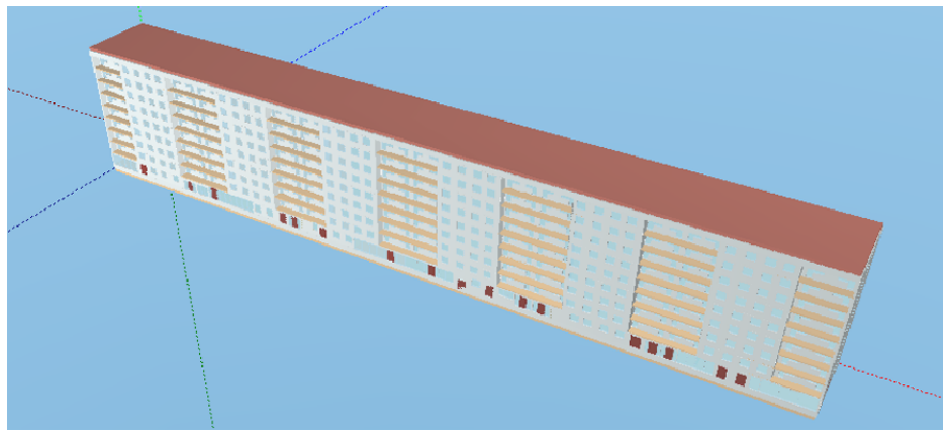

Fig. 3. Building 3 - visualization made in the Audytor OZC 6.6 Pro program.

The calculations were made with the assumption that the internal temperature in buildings is kept at $20^{\circ} \mathrm{C}$. Both measured temperature and the buildings' residents indicated however, that in reality temperature is kept at a lower level. In order to verify this, the amount of usable energy was converted into final energy and then compared with the actual energy consumption in buildings. Then the variants with different temperatures were analyzed, which indicated that the temperature in the buildings is about $17^{\circ} \mathrm{C}$. Further calculations assumes this temperature.

Therefore, at the beginning, two variants were proposed for each of the buildings. Both modernization variants assume the same basic state before thermomodernization, in which the average internal temperature is $17^{\circ} \mathrm{C}$. A list of possible upgrades is identical for all the buildings and includes: insulation of walls and roofs, replacement of window and door carpentry in common areas and modernization of heating installations.

In order to select the most economical solution, several upgrade variants were analyzed for each thermomodernization activity. The costs of individual thermomodernization measures and the annual financial savings resulting from their implementation were listed. The upgrade variants in which the quotient of cost and savings was the lowest (the lowest SPBT - Simple Pay Back Time) were selected. Selected solutions are summarized below:

- insulation of external walls with mineral wool (with a thermal conductivity coefficient $\lambda=0.031 \mathrm{~W} / \mathrm{m} \cdot \mathrm{K}$ ), thickness of $13 \mathrm{~cm}$ (buildings 1 and 3) and $14 \mathrm{~cm}$ (building 2) - change in the heat transfer coefficient from approximately $1.2-1.3 \mathrm{~W} / \mathrm{m}^{2} \mathrm{~K}$ to $0.19 \mathrm{~W} / \mathrm{m}^{2} \mathrm{~K}$;

- insulation of the ventilated flat roof with granular mineral wool (with a thermal conductivity coefficient $\lambda=0.040 \mathrm{~W} / \mathrm{m} \cdot \mathrm{K}$ ), thickness of $23 \mathrm{~cm}$ - change in the heat transfer coefficient from approximately $0.95 \mathrm{~W} / \mathrm{m}^{2} \mathrm{~K}$ to $0.15 \mathrm{~W} / \mathrm{m}^{2} \mathrm{~K}$;

- replacement of staircase windows with a heat transfer coefficient of $2.9 \mathrm{~W} / \mathrm{m}^{2} \mathrm{~K}$ for new plastic windows $\left(\mathrm{U}=0.9 \mathrm{~W} / \mathrm{m}^{2} \mathrm{~K}\right)$;

- replacement of old doors with a heat transfer coefficient of $2.85 \mathrm{~W} / \mathrm{m}^{2} \mathrm{~K}$ for aluminum doors $\left(\mathrm{U}=1.3 \mathrm{~W} / \mathrm{m}^{2} \mathrm{~K}\right)$;

- modernization of the heating installation - increase in the total system efficiency from 0.5852 to 0.7524 (partial efficiency was determined based on the Polish Regulation [1]).

Figure 4 presents the demand for usable and final energy consumption in the buildings in the state before and after deep thermomodernization. The cost of 1 GJ of final energy was set at $339 \mathrm{UAH} / \mathrm{GJ}$. The gross price of UAH/GJ was taken after $1^{\text {st }}$ July 2016 (after price increases). Final energy consumption in buildings 1 and 3 (in terms of $\mathrm{kWh} / \mathrm{m}^{2} /$ year) is at a similar level. This value in building 2 is lower and it is due to the fact that over $74 \%$ of the building's surface is heated (in buildings 1 and 3 this value is around 55-60\%), and the energy consumption indicator is related to the unit of the heated area. 


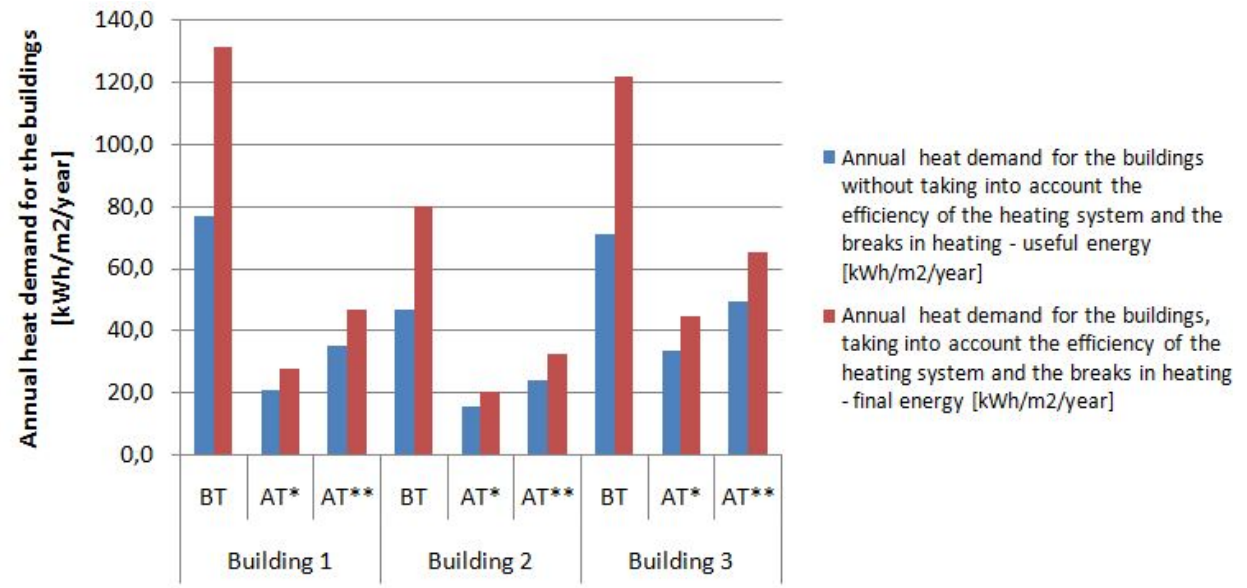

Fig. 4. Annual heat demand for the buildings.

BT - before thermomodernization, AT - after thermomodernization.

* with assumption that internal temperature is $17^{\circ} \mathrm{C}$ before and after thermomodernization.

** with assumption that internal temperature is $17^{\circ} \mathrm{C}$ before and $20^{\circ} \mathrm{C}$ after thermomodernization.

Due to the still growing prices of thermomodernization materials in Ukraine and a very difficult assessment of how much these prices will change after thermomodernization, it was decided to set the costs of selected modernizations at the current prices level in Poland (in subsequent calculations $1 \mathrm{PLN}=6.72 \mathrm{UAH}$ - average exchange rate of the National Bank of Poland for April 12 $2^{\text {th }}$ 2017). The predicted total costs of labor and materials, as well as estimated savings depending on the variant, are presented in table 2 . Assuming that after thermomodernization the temperature in buildings will remain at the level before thermomodernization the theoretical reduction in final energy demand will go down to approx. $64 \%$ in building 3,74\% in building 2 and $79 \%$ in building 1 . In variant which assures increasing indoor temperature to $20{ }^{\circ} \mathrm{C}$ the total demand for final energy compared to the value from before thermomodernization is lower approx. $46 \%$ in building 3,57\% in building 2 and 64\% in building 1 .

Table 2. Economic characteristics of the optimal variant of the thermomodernization project.

\begin{tabular}{|l|c|c|c|c|}
\hline Description & Unit & Building 1 & Building 2 & Building 3 \\
\hline Planned total costs & {$[\mathrm{UAH}]$} & $3,753,023$ & $9,037,879$ & $21,118,701$ \\
\hline $\begin{array}{l}\text { Annual theoretical final energy } \\
\text { cost savings* }\end{array}$ & {$[\mathrm{UAH} / \mathrm{year}]$} & 135,058 & 306,659 & 998,965 \\
\hline $\begin{array}{l}\text { Annual theoretical reduction in } \\
\text { final energy demand* }\end{array}$ & {$[\%]$} & 78.7 & 74.3 & 63.4 \\
\hline Simple Pay Back Time (SPBT) * & {$[$ years] } & 27.8 & 29.5 & 21.1 \\
\hline $\begin{array}{l}\text { Annual theoretical final energy } \\
\text { cost savings** }\end{array}$ & {$[\mathrm{UAH} / \mathrm{year}]$} & 110,107 & 246,080 & 728,511 \\
\hline $\begin{array}{l}\text { Annual theoretical reduction in } \\
\text { final energy demand** }\end{array}$ & {$[\%]$} & 64.2 & 59.6 & 46.3 \\
\hline Simple Pay Back Time (SPBT) & [years] & 34.1 & 36.7 & 29.0 \\
\hline
\end{tabular}

* with assumption that internal temperature is $17^{\circ} \mathrm{C}$ before and after thermomodernization

$* *$ with assumption that internal temperature is $17^{\circ} \mathrm{C}$ before and $20^{\circ} \mathrm{C}$ after thermomodernization 
The demand for final energy in buildings in Figure 4 is lower than in buildings characterized by similar external partitions parameters. This is mainly due to the fact that analyzed buildings have internal temperatures lower than $20^{\circ} \mathrm{C}$ (approximately $17^{\circ} \mathrm{C}$ ), ventilation is very poor (ventilation airflow limited by users) and the demand of hot water preparation is not considered in results. In recent years the value of Ukrainian Hryvna is unstable, beacuse of it the polish prices of materials and labor were used in calculations (these Polish prices are even twice as high). Because of this fact the SPBT of selected thermo-modernization measures are high (Table 2).

Table 3 presents the share of the costs of individual thermomodernization actions, which are summarized in Table 3.

Table 3. Economic characteristics of the optimal variant of the thermomodernization project.

\begin{tabular}{|l|c|c|c|c|c|c|}
\hline \multirow{2}{*}{ Kind of modernization } & \multicolumn{3}{|c|}{ Participation in the entire thermomodernization } \\
\cline { 2 - 7 } & \multicolumn{2}{|c|}{ Building 1 } & \multicolumn{2}{c|}{ Building 2 } & \multicolumn{2}{c|}{ Building 3 } \\
\cline { 2 - 7 } & $\mathrm{UAH}$ & $\%$ & $\mathrm{UAH}$ & $\%$ & $\mathrm{UAH}$ & $\%$ \\
\hline Insulation of external walls & $1,834,890$ & 48.9 & $5,048,215$ & 55.9 & $12,675,888$ & 60.0 \\
\hline $\begin{array}{l}\text { Insulation of external walls } \\
\text { of cellar }\end{array}$ & 173,074 & 4.6 & 0 & 0.0 & 0 & 0.0 \\
\hline Insulation of the roof & 595,741 & 15.9 & $1,340,816$ & 14.8 & $2,132,096$ & 10.1 \\
\hline $\begin{array}{l}\text { Staircase window } \\
\text { replacement }\end{array}$ & 86,930 & 2.3 & 243,855 & 2.7 & 735,437 & 3.5 \\
\hline Staircase door replacement & 61,907 & 1.6 & 296,675 & 3.3 & 358,047 & 1.7 \\
\hline $\begin{array}{l}\text { Modernization of the } \\
\text { heating installation }\end{array}$ & 870,480 & 23.2 & $1,978,318$ & 21.9 & $5,087,233$ & 24.1 \\
\hline Documentation & 130,000 & 3.5 & 130,000 & 1.4 & 130,000 & 0.6 \\
\hline Sum & $3,753,023$ & 100.0 & $9,037,879$ & 100.0 & $21,118,701$ & 100.0 \\
\hline
\end{tabular}

In all three buildings, the highest share of cost of thermomodernization actions is the insulation of external walls. The larger the building and the greater the ratio of the wall area to the entire surface of the whole external partitions, the greater the share of the wall insulation cost in the whole cost, which in the case of building 3 is $60 \%$ of the total cost of thermomodernization. In all buildings, the costs of modernizing the heating system have a similar share in the total costs, which results from the adopted assumption of dependency of the price of such an operation on the number of heaters in the facility.

As shown in table 2 , in variants that assume improvement of thermal comfort, including increase of the internal temperature from $17^{\circ} \mathrm{C}$ to $20^{\circ} \mathrm{C}$, the energy and financial savings are reduced in comparison to the variants in which this temperature is not increased. However, it is recommended to improve this situation. Simple Pay Back Time (SPBT), assuming a fixed price of heat in time, are at the level of 30-34 years.

As an additional thermomodernization activity, a photovoltaic installation can be also considered. Despite the fact that this type of installation is used to produce electricity, the resulting financial gains can be used to repay thermomodernization activities reducing heat demand. The selection of photovoltaic installations is presented in the chapter 3.2.

\subsection{Selection of photovoltaic installations}

In this chapter, the selection of a photovoltaic (PV) system for each building was analyzed. PV systems will supply electricity for the common parts of the buildings while the surplus energy will be sold to the grid. Electricity usage in the common parts of the building results mostly from demand for lighting, which is energy-efficient. In addition, there are lifts 
in building 3. There is a support system for photovoltaic installations currently in force in Ukraine. According to the support system it is possible to install a PV system with a power not exceeding the ordered power for the building, but no more than $30 \mathrm{~kW}_{\mathrm{p}}$. In both analyzed buildings ordered power is lower than $30 \mathrm{~kW}_{\mathrm{p}}$. However, it was assumed that if the roof surface is large enough it will be possible to increase this power to $30 \mathrm{~kW}_{\mathrm{p}}$. It was estimated that $20 \mathrm{~kW}_{\mathrm{p}}$ of photovoltaic panels could be installed in the first building and $30 \mathrm{~kW}_{\mathrm{p}}$ in the remaining buildings. Use of typical polycrystalline modules with nominal power of $250 \mathrm{~W}_{\mathrm{p}}$ and $15.3 \%$ efficiency was assumed for each system. In order to maximize solar profits, PV panels should be placed on the roof on a frame at an angle of $35^{\circ}$ and directed towards the south. Calculations of electricity amount produced by PV installations for the considered buildings were made using the solar irradiation values taken from the RETScreen program. In all three buildings, the rate for purchasing electricity in 2016 was $1.68 \mathrm{UAH} / \mathrm{kWh}$. According to the Ukrainian law in case of buildings like those assessed the principle of monthly energy balancing and settlements with the energy producer applies. If the monthly amount of energy produced by PV installations is greater than the amount of energy for the building's own needs the surplus is rewarded with a "green tariff", the value of which depends on the period in which the installation was installed. For the period $1^{\text {st }}$ January $2017-31^{\text {st }}$ December 2019 , it is $-6.2271 \mathrm{UAH} / \mathrm{kWh}$. The average annual production of electricity in the proposed photovoltaic installations gives an efficiency of $1,168 \mathrm{kWh} / \mathrm{kW}_{\mathrm{p}}$ per year. The financial balances were calculated by comparing the above data with the demand for electricity in common parts of the buildings. The outcomes are summarized in Table 4. For further calculations, the total PV installation price was assumed at $43,680 \mathrm{UAH} / \mathrm{kW}_{\mathrm{p}}$.

Table 4. Electricity usage in common areas in the buildings calculated for 2016.

\begin{tabular}{|l|c|c|c|c|c|c|c|}
\hline \multirow{3}{*}{ Building } & \multicolumn{2}{|c|}{$\begin{array}{c}\text { Electricity } \\
\text { consumption by the } \\
\text { common parts of the } \\
\text { buildings }\end{array}$} & \multicolumn{2}{|c|}{$\begin{array}{c}\text { Electricity saving- } \\
\text { electricity } \\
\text { production by the } \\
\text { PV }\end{array}$} & \multicolumn{2}{|c|}{$\begin{array}{c}\text { Surplus electricity } \\
\text { sold to the network }\end{array}$} & $\begin{array}{c}\text { Yearly } \\
\text { profit }\end{array}$ \\
\cline { 2 - 8 } & $\mathrm{UAH}$ & $\mathrm{kWh}$ & $\mathrm{UAH}$ & $\mathrm{kWh}$ & $\mathrm{UAH}$ & $\mathrm{kWh}$ & $\mathrm{UAH}$ \\
\hline Building 1 & 7,379 & 4,392 & 7,379 & 4,392 & 118,116 & 18,968 & 125,494 \\
\hline Building 2 & 2,409 & 1,434 & 2,409 & 1,434 & 209,268 & 33,606 & 211,677 \\
\hline Building 3 & 31,518 & 18,761 & 27,362 & 16,287 & 116,777 & 18,753 & 144,139 \\
\hline
\end{tabular}

Building 1 and building 2 do not have a lift and in these cases the electricity demand is much lower than the value of electricity produced by the PV installation. Therefore, the greater part of the energy is sold to the network, and the income for its sale is higher. In the elevator-equipped building 3 the situation is different and variant is less profitable than in 1-st and 2-nd building. In every case monthly balances of electricity and the excess energy is sold to the network are created. "The green tariff" is almost four times higher than the price of energy purchased in the network. Thus, the most advantageous solution that brings the fastest return on investment is the variant in which the building consumes the least amount of electricity and sells to the network as much electricity as possible. Below in Figures $4-6$, the monthly breakdown of electricity demand in the common parts of buildings 1-3 and the production from photovoltaic installations designed for these buildings are listed. 


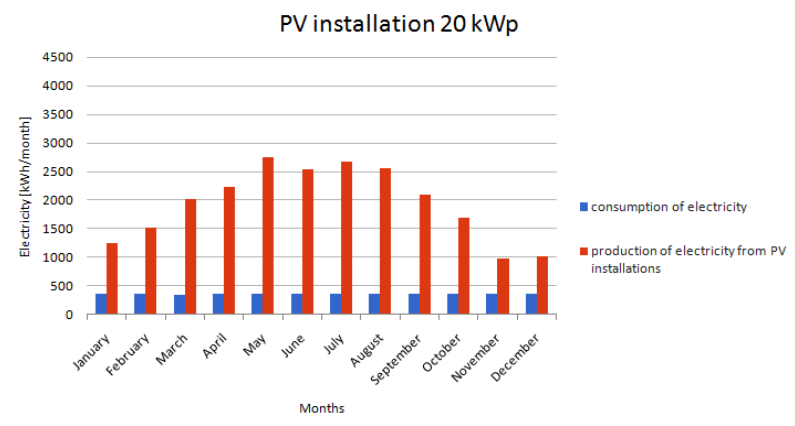

Fig. 4. Consumption of electricity by the Building 1 and production electricity from $20 \mathrm{~kW}_{\mathrm{p}}$ photovoltaic installation.

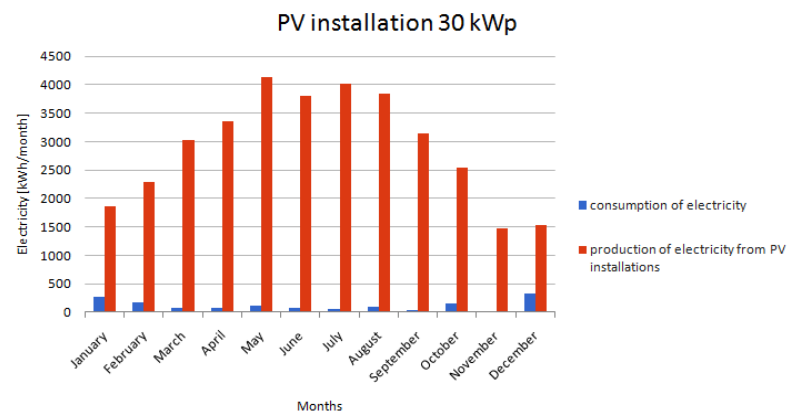

Fig. 5. Consumption of electricity by the Building 2 and production electricity from $30 \mathrm{~kW}_{\mathrm{p}}$ photovoltaic installation.

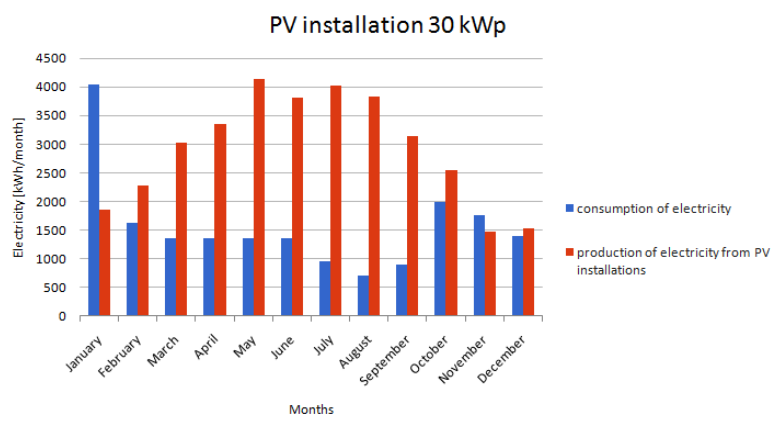

Fig. 6. Consumption of electricity by the Building 3 and production electricity from $30 \mathrm{~kW}_{\mathrm{p}}$ photovoltaic installation.

\subsection{Thermomodernization and photovoltaics}

In this chapter the data related to the variants assuming only thermomodernization and variants assuming thermomodernization expanded with photovoltaic installations is collected and presented. The data is presented in Table 5. Inclusion of heating and electricity into joint analysis is not typical, however it serves an important function in calculation of potential financial savings, both resulting from the reduction of heat consumption and from the electricity sold to the grid. Money obtained from the sale of electricity can be used not only to pay off the solar installation, but also to other thermomodernization activities. A detailed description of the main conclusions is given in Chapter 4. 
Table 5. Energy specification of the buildings (heat + electricity for common parts).

\begin{tabular}{|c|c|c|c|c|c|c|c|}
\hline \multirow{2}{*}{ Description } & \multirow{2}{*}{ Unit } & \multicolumn{2}{|c|}{ Building 1} & \multicolumn{2}{|c|}{ Building 2} & \multicolumn{2}{|c|}{ Building 3} \\
\hline & & BT & AT & BT & AT & \begin{tabular}{l|l} 
BT \\
\end{tabular} & AT \\
\hline \multirow{2}{*}{$\begin{array}{l}\text { Annual heating demand for } \\
\text { heating the building without } \\
\text { taking into account the efficiency } \\
\text { of the heating system and the } \\
\text { breaks in heating - final energy* }\end{array}$} & {$[\mathrm{kWh} /$ year] } & 140,556 & 29,889 & 338,278 & 87,000 & $1,290,333$ & 471,778 \\
\hline & [UAH/year] & 171,534 & 36,476 & 412,834 & 106,175 & $1,574,723$ & 575,758 \\
\hline \multirow{2}{*}{$\begin{array}{l}\text { Annual heating demand for } \\
\text { heating the building without } \\
\text { taking into account the efficiency } \\
\text { of the heating system and the } \\
\text { breaks in heating - final } \\
\text { energy** }\end{array}$} & [kWh/year] & 140,556 & 50,333 & 338,278 & 136,639 & $1,290,333$ & 693,389 \\
\hline & [UAH/year] & 171,534 & 61,427 & 412,834 & 166,754 & $1,574,723$ & 846,212 \\
\hline \multirow{2}{*}{$\begin{array}{l}\text { Electricity demand for common } \\
\text { parts of the building }\end{array}$} & [kWh/year] & 4,392 & 0 & 1,434 & 0 & 18,761 & 0 \\
\hline & [UAH/year] & 7,379 & 0 & 2,409 & 0 & 31,518 & 0 \\
\hline \multirow{2}{*}{ Electricity sold to the grid } & [kWh/year] & 0 & 18,968 & 0 & 33,606 & 0 & 18,753 \\
\hline & [UAH/year] & 0 & 118,116 & 0 & 209,268 & 0 & 116,777 \\
\hline \multirow{2}{*}{ Final energy + electricity* } & [kWh/year] & 144,948 & 29,889 & 339,712 & 87,000 & $1,309,094$ & 471,778 \\
\hline & [UAH/year] & 178,913 & $-81,639$ & 415,243 & $-103,093$ & $1,606,241$ & 458,981 \\
\hline \multirow{2}{*}{ Final energy + electricity** } & [kWh/year] & 144,948 & 50,339 & 339,709 & 136,652 & $1,309,103$ & 695,851 \\
\hline & [UAH/year] & 178,913 & $-56,689$ & 415,243 & $-42,514$ & $1,606,241$ & 729,435 \\
\hline
\end{tabular}

$\mathrm{BT}$ - before thermomodernization, AT - after thermomodernization

* with assumption that internal temperature is $17^{\circ} \mathrm{C}$ before and after thermomodernization

** with assumption that internal temperature is $17^{\circ} \mathrm{C}$ before and $20^{\circ} \mathrm{C}$ after thermomodernization

\section{Analysis of results and conclusions}

Collection of all the results presented in the tables in Chapter 3 allowed the final analysis and conclusions. The most important data was selected and summarized in Table 6. Each proposed modernization variant brings savings, both in terms of energy and money.

Table 6. Summary of the most important parameters: energy costs, energy savings, SPBT for individual investments.

\begin{tabular}{|l|c|c|c|c|}
\hline Description & Unit & Building 1 & Building 2 & Building 3 \\
\hline The cost of thermomodernization & {$[\mathrm{UAH}]$} & $3,753,023$ & $9,037,879$ & $21,118,701$ \\
\hline The cost of PV installation & {$[\mathrm{UAH}]$} & 873,600 & $1,310,400$ & $1,310,400$ \\
\hline $\begin{array}{l}\text { Reduction of energy charges (only heating) - } \\
\text { without PV * }\end{array}$ & {$[\mathrm{UAH} /$ year] } & 135,058 & 306,659 & 998,965 \\
\hline $\begin{array}{l}\text { Reduction of energy charges (heating and } \\
\text { electricity) - with PV * }\end{array}$ & {$[\mathrm{UAH} /$ year] } & 260,552 & 518,336 & $1,147,260$ \\
\hline $\begin{array}{l}\text { Reduction of energy charges (only heating) - } \\
\text { without PV ** }\end{array}$ & {$[\mathrm{UAH} /$ year] } & 110,107 & 246,080 & 728,511 \\
\hline $\begin{array}{l}\text { Reduction of energy charges (heating and } \\
\text { electricity) - with PV ** }\end{array}$ & {$[\mathrm{UAH} /$ year] } & 235,601 & 457,757 & 876,806 \\
\hline SPBT (only heating) - without PV * & {$[$ years] } & 27.8 & 29.5 & 21.1 \\
\hline SPBT (heating and electricity) - with PV * & {$[$ years] } & 17.8 & 20.0 & 19.6 \\
\hline SPBT (only heating) - without PV ** & {$[$ years] } & 34.1 & 36.7 & 29.0 \\
\hline SPBT (heating and electricity) - with PV ** & {$[$ years] } & 19.6 & 22.6 & 25.6 \\
\hline
\end{tabular}

* with assumption that internal temperature is $17^{\circ} \mathrm{C}$ before and after thermomodernization

** with assumption that internal temperature is $17^{\circ} \mathrm{C}$ before and $20^{\circ} \mathrm{C}$ after thermomodernization 
As previously indicated in chapter 3.1, for thermomodernization containing all the indicated variants reducing the heat demand and bringing the indoor temperature of buildings to $20^{\circ} \mathrm{C}$, SPBT was at the level of 30-34 years. The photovoltaic system can improve combined financial results. Under the assumptions presented in sub-chapter 3.2, PV installations will cover $100 \%$ of the electricity demand for common parts in the analyzed buildings and additional energy will be sold to the electricity grid. It will allow obtaining additional income that will reduce SPBT. Variants assuming this option reduce SPBT to 20-26 years. It is a long payback period but it is acceptable assuming that PV installations are designed for a long technical lifetime and the thermomodernization measures carried out will bring beneficial effects for even longer periods of time. An additional unknown, which may favorably affect the proposed investments, are the costs of electricity and heat, which in Ukraine are systematically growing, much faster than in other countries in this region.

Comprehensive thermomodernization activities in old, uninsulated buildings are needed and they can bring visible effects. Both operating costs and energy consumption can be reduced by up to 3-4 times. Additional benefits may come from the use of renewable energy sources. The combination of all these activities at once, on a multi-building scale, reduces unit costs of the entire investment while simultaneously improving the comfort of use of the buildings.

\section{References}

1. Regulation of Minister of Infrastructure and Economic Development (21 February, 2015) on the methodology for determining the energy performance of building or part of the building and energy performance certificates

2. PN EN ISO 13790 : Energy performance of buildings -- Calculation of energy use for space heating and cooling

3. PN EN ISO 6946: Building components and building elements -- Thermal resistance and thermal transmittance -- Calculation method 